"Mircea cel Batran" Naval Academy Scientific Bulletin, Volume XX - 2017 - Issue 2

The journal is indexed in: PROQUEST / DOAJ / Crossref / EBSCOhost/ INDEX COPERNICUS/ OAJI / DRJI I

JOURNAL INDEX / I2OR / SCIENCE LIBRARY INDEX / Google Scholar / Academic Keys / ROAD Open Access I Academic Resources / Scientific Indexing Services / SCIPIOI JIFACTOR

\title{
COOPERATIVE TEACHING VS. TRADITIONAL TEACHING IN DEVELOPING ESP SPEAKING SKILLS. AN EXPERIMENTAL STUDY
}

\author{
Lavinia NADRAG ${ }^{1}$ \\ Alina BUZARNA-TIHENEA (GALBEAZA) \\ ${ }^{1}$ Prof. PhD Faculty of Letters, Ovidius University of Constanta, Aleea Universitatii no. 1, Campus, Corp A, \\ Lnadrag28@yahoo.com \\ ${ }^{2}$ Assist. Prof. PhD of Letters, Ovidius University of Constanta, Aleea Universitatii no. 1, Campus, Corp A, \\ alina_buzarna84@yahoo.com
}

\begin{abstract}
Recent studies have shown that EFL/ESL skills, in general, and ESP skills, in particular, are better developed when modern and innovative student-centered teaching and learning methods and techniques are employed, such as the communicative approach, cooperative teaching and learning, creative teaching and teaching for creativity, contextual learning, cross-over learning, computational thinking, adaptive teaching, embodied learning, etc. The purpose of this paper is to underline the efficiency of cooperative learning, compared to traditional teaching methods, in developing the students' ESP speaking skills. This paper is part of an experimental study conducted on two groups of students whose major is Business Economics (first year of study), over a period of one month, in the first semester of the academic year 20162017. The control group consisted of 25 students while the experimental group had 20 students. The experimental study involved the following stages: an initial test was applied to both groups of students, in order to assess their initial ESP skills; afterwards, two ESP units were taught, i.e. "Tomorrow's World" and "Job Interviews". The traditional methods and techniques were used when teaching ESP to the control group, while techniques specific to cooperative teaching and learning were applied to the experimental group. At the end of the teaching period, a final test was taken by the students of both groups in order to assess the effectiveness of the two teaching methods and techniques that had been used during the ESP seminars (i.e. the traditional and the cooperative one), focused on developing the students' ESP skills. Moreover, the students answered a questionnaire assessing their opinions and attitudes towards the applied teaching methods.
\end{abstract}

Keywords: cooperative learning, traditional teaching, ESP, Business Economics, speaking skills

\section{Introduction}

ESP cooperative learning implies teaching by organizing students in small teams (each team consisting of students of different ESP skill levels) and using a wide range of ESP learning activities and tasks in order develop their understanding. It is noteworthy that, when it comes to cooperative learning, every team member holds the responsibility for learning what is taught and for helping their team colleagues learn (Castillo, 2007:85). Therefore, this method engenders an achievement environment. While performing their task, students are also required to ensure that all team members successfully understood and completed it. The students' cooperative efforts generate reciprocal benefits for all team members. Moreover, by sharing the same task, they become acquainted with each other's performance and skill levels and are aware of the fact that performances are influenced both by oneself and by the other team members. Upon the successful achievement of the task, the students usually feel very proud and they are happy when a team member's success is acknowledged, because this is also the success of the entire team. Thus, cooperative learning triggers more opportunities for students to get involved more actively in the learning process (Adams, 2013).
Cooperative learning: concept and techniques Speaking is playing a more and more important role in learning any foreign language, since the learners' main purpose is represented by the acquisition of the ability to communicate and to understand the messages transmitted in the respective language. In cooperative learning, discussions are indispensable tools, especially when it comes to the development of the speaking skills, as they represent a better alternative to the question-and-answer method, giving students more freedom of expression (Johnson et al., 1998). However, discussions also have several drawbacks when applied at the level of the entire class because shy and less confident students can hide from the teacher and avoid contributing to the respective discussion-based activity. Therefore, in order to promote productive talk, students should be organized in pairs or small groups, in order to discuss and solve a specific task (Meng, 2010: 701-702). Through cooperative learning, speaking activities can be highly motivating and students are willing to express their views, to express themselves instead of being afraid of making mistakes in front of the whole class (Meng, 2010: 703). 


\section{"Mircea cel Batran" Naval Academy Scientific Bulletin, Volume XX - 2017 - Issue 2 \\ The journal is indexed in: PROQUEST / DOAJ / Crossref / EBSCOhost/ INDEX COPERNICUS/ OAJI / DRJI I JOURNAL INDEX / I2OR / SCIENCE LIBRARY INDEX / Google Scholar / Academic Keys / ROAD Open Access I Academic Resources / Scientific Indexing Services / SCIPIOI JIFACTOR}

Among the numerous factors which have an impact on the results of learning, Ryan and Deci (2000: 55-61) enlarge on the concept of motivation, its definition and classification: "intrinsic motivation, which refers to doing something because it is inherently interesting or enjoyable, and extrinsic motivation, which refers to doing something because it leads to a separable outcome. "Intrinsic motivation results in high-quality learning and creativity" while external motivation is classified into external regulation, introjection, identification, integration. On the other hand, amotivation "is the state of lacking an intention to act".

In Frandsen's opinion (1994), it is clear that physical conditions influence the learning process and can alter the students' motivation either positively or negatively. Thus, teachers should try to make their classrooms as pleasant as possible. For instance, even where conditions are bad, it may be possible to improve the atmosphere with posters or by displaying the students' work on walls.

Thus, compared to the traditional classroom, where students are passive and work alone, the teacher directing their work, the cooperative classroom encourages students to be active, to direct their work by themselves and to work either in pairs or in small groups made of up to six students. If in the traditional classroom the teacher is the one who initiates the discussions, silence being valued, the cooperative classroom teaches students to initiate discussions, the learning noise being appropriate. On the one hand, in the traditional classroom, not all students have the opportunity to participate and the focus falls upon individual accountability, the students being encouraged to become independent learners and being provided with individual materials. Moreover, feed-back comes only from the teacher. On the other hand, as far as the cooperative classroom is concerned, all students are provided with different occasions to participate actively in order to solve tasks. Having in view that, in the cooperative classroom the focus is placed on individual and team responsibility, students are encouraged to become interdependent learners, being given shared materials (Bawn, 2007; Macpherson, 2007). Furthermore, feedback also comes from the students' peers. The teacher's role is to help and encourage students to develop their skills, but without relinquishing a more traditional role as a source of information, advice and knowledge (Jones, 2007: 25).

Therefore, cooperative learning relies on a wide variety of classroom interaction types, such as collaborative learning, discussions, debates, roleplay, interactive sessions, loud reading, storytelling, conversation with learner (Sanchez, 2010;
Stone, 2007). These techniques contribute heavily to the development of students' ESP skills (especially the speaking and listening ones) and enhance their ability to think critically and to share their opinions with their colleagues, as they involve emotions, creativity, agreement/ disagreement, gestures, spontaneity. Cooperative learning encourages student-student interaction, which relies on group work or pair work. In this case, stress is reduced as students group with their classmates for discussions and help each other. The teacher plays a less dominant role, being only the monitor, while the students are the main participants to the activities, dominating their own interaction process (Gillies and Ashman, 2003). Moreover, they will develop their selfcorrecting abilities as they learn to avoid making the same mistakes that their peers have made before.

Among the benefits of cooperative learning, one can notice: the increase in the students' achievements, their becoming responsible for their own learning, retention improvement, the generation of more positive feelings towards the subject studied, the promotion of active learning, lower frustration and anxiety levels, promotion of inter-personal communication abilities, enhancement of self-worth feelings and the creation of a sense of community (Wilwert, 2015; Zhang, 2010).

In order to be able to monitor each group, the teacher should provide clear guidance and directions before asking the students to practice interactional activities in their respective groups. Furthermore, in order to better organize the class, Jones (2007: 8) provides the following pieces of advice: talkative students should be organized in groups of three and less talkative students in groups of four or five; in order to stimulate a better exchange of ideas, shy students should be organized in groups of three rather than in pairs; the teacher can ask two students to discuss while a third one listens to their conversation, takes notes and provides feedback at the end.

\section{Class activities for developing speaking skills. Concepts and techniques}

It is widely known that communication plays a very important role in ESP teaching and learning, so that learners acquire the necessary speaking skills in order to be successful on the contemporary highly competitive and globalized labor market (Mărunțelu and Dumitrașcu, 2013). In order to develop the students' ability to speak fluently, the teacher should have in view not only their knowledge of language features but also their ability to process both the received information and the used language (at the same time) and to structure their discourse. Often, this triggers the need for further clarification by the 


\section{"Mircea cel Batran" Naval Academy Scientific Bulletin, Volume XX - 2017 - Issue 2 \\ The journal is indexed in: PROQUEST / DOAJ / Crossref / EBSCOhost/ INDEX COPERNICUS/ OAJI / DRJI I JOURNAL INDEX / I2OR / SCIENCE LIBRARY INDEX / Google Scholar / Academic Keys / ROAD Open Access I Academic Resources / Scientific Indexing Services / SCIPIOI JIFACTOR}

teacher (Harmer, 2003: 271). When conducting speaking activities in the cooperative ESP classroom, the teacher should bear in mind two basic oral communication types, i.e. conversational (dialogic) and expositional (monological).

The conversational mode has an interactional and communicative nature and it is the most widely used. It relies on the rapid exchange of information and, in the ESP classroom, it can take the form of enjoyable and stimulating activities that involve the transfer of information from one person to another that "catch" the students' attention and reduce their anxiety, activities such as question-answer based tasks, brainstorming, conversations, simulations, role play, improvisations and debates on different proposed topics. Moreover, the texts used in the classroom provide opportunities for role play and improvisation, interactive conversation and communication, which, if performed regularly, gradually improve the students' abilities to master essential communication strategies (Vizental, 2007: 109).

As far as the expositional mode is concerned, the speaker delivers freely an informative (introducing oneself, for instance), descriptive (describing something), narrative (storytelling), persuasive (persuade somebody to do something, expressing opinions) presentation on a certain topic, in front of an audience, stimulating the students' ability to speak fluently and freely. The expositional mode may include activities such as describing a person, expressing opinions on a given topic, telling a story, commenting on a text/an event, delivering a speech. The students can be asked to speak spontaneously (called on to express their opinions without preparation), or they may be given an of time to prepare what they want to say. To foster the students to speak, the teacher must lead them from fully controlled activities, through guided activities to free communication. In the early stage of language teaching, the students learn basic vocabulary items and structures through drills and exercises, controlled activities (in which language is controlled by the teacher), the focus being on ways of producing correct language (Vizental 2007: 210-216).

The next stage is represented by guided practice, which consists in controlled activities aimed at providing support and confidence, where students produce language by imitating the model provided by the teacher. Nevertheless, repetition does not lead to the actual production of language and, therefore, students should move as far away from the models as possible in order to get ready for real life, and carry out activities involving interaction, creation of messages, information transfer. Thus, the students can express themselves in progressively creative contexts.
Guided speaking activities require students to produce texts similar to those provided by the teacher, but in a different way, by paraphrasing the words of the initial text (not repeating them) or by using one's own imagination and expanding the respective text. The most common type of guided conversation is represented by the question-answer exchange, related to the studied text. Students should be motivated, they should involve in conversations on topics similar to those in the real world and close to their own experiences, such as home, family, shopping, travelling, music, professions. Besides conversations, other guided speaking activities include joining or reordering slashed words, sentences, or paragraphs, continuing sentences or paragraphs according to one's own imagination, using linguistic or non-linguistic props (such as key words, pictures) to form their own texts (Mărunțelu, 2006).

The next step, i.e. free language production and communication (involving the independent collecting of material and production of own texts), can be applied after the students have developed language fluency and proficiency (usually at intermediate and advanced levels) and involved activities such as dialogues, role play and improvisation. The teacher organizes the activities, facilitates the interactions, moderates and analyzes the students' free language production.

It is noteworthy that speaking activities can take place at any stage of the lesson, i.e. as prereading or pre-listening activities, as while-reading or while-listening activities or as after-reading or after-listening activities. However, they should be managed and organized differently, having in view factors such as the lesson stage, the text type, the lesson's objectives, the students' age and language level.

\section{Case study}

This second section of the paper is a case study, centered on the comparison between Cooperative Language Learning and Traditional Language Learning, with a focus on the ESP speaking skills. The study was based on the following hypothesis: When using the Cooperative Learning Method in the ESP classroom, learners feel more comfortable and their speaking Skills are enhanced. Therefore, it is aimed at analyzing and assessing the influence that cooperative learning and traditional learning methods and techniques have on the students' ESP Speaking Skills.

The research instruments used for the purpose of this research were: speaking tests used as initial tests and final tests, the experiment and the observation. During the experimental stage, we also used different types of exercises including matching, cloze, true or false, riddles, crosswords, 
"Mircea cel Batran" Naval Academy Scientific Bulletin, Volume XX - 2017 - Issue 2

The journal is indexed in: PROQUEST / DOAJ / Crossref / EBSCOhost/ INDEX COPERNICUS/ OAJI / DRJI I JOURNAL INDEX / I2OR / SCIENCE LIBRARY INDEX / Google Scholar / Academic Keys / ROAD Open Access I Academic Resources / Scientific Indexing Services / SCIPIOI JIFACTOR

rephrasing exercises. In addition, the students were encouraged to engage in debates and short dialogues, interviews, descriptions, storytelling, summarizing, expressing opinions, in connection to their field of study, i.e. business economy.

This case study was conducted in two parallel groups majoring in Business Economy, over one month, in academic year 2016/2017, in order to analyze the efficiency of cooperative learning and traditional learning on the students' ESP speaking skills. The experimental group (where cooperative learning was used) consisted of 20 students (divided into five teams of four members) and the control group (which studied and developed their ESP speaking skills by means of traditional, teacher-centered methods) had 25 students.

The lesson plans for both groups addressed the same instructional objectives based on the same speaking topics and exercises. However, the lesson plans for the experimental group were based on cooperative learning and provided opportunities for small-group interaction and sharing resources among team members. As far as the control group students were concerned, they were asked to solve their tasks individually and shared their answers with the class, their activities being based only on student-teacher interactions. Worksheets were provided to both groups; however, the control group was provided with traditional routine situations.

Before the experiment, an initial test was administered to both groups in order to assess the students' ESP level and the differences between the two groups, in terms of their ESP skills. The initial test contained three tasks: answer some questions, talk about picture differences and express your opinion on a particular topic. The procedure of the test provided the measure of performance quality, according to the following criteria: pronunciation (intelligibility degree, intonation, sentence and word stress, articulation of individual sounds), grammar and vocabulary accuracy (control of grammatical forms, range of appropriate vocabulary items, ability to exchange views on unfamiliar and abstract topics), discourse management (language style, types of contributions, range of cohesive devices and discourse markers) and interactive communication (linking/ not linking contributions to those of other speakers; scope of interaction; negotiation towards an outcome).

The results of the initial tests provided the following pieces of information in terms of the students' speaking skills, and they are presented in the table below:

Table 1. The students' speaking skills. Levels and criteria (initial test results)

\begin{tabular}{|c|c|c|c|}
\hline Ј & 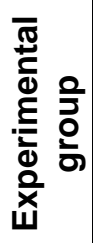 & $\begin{array}{l}\frac{0}{2} \\
0 \\
\frac{0}{0} \\
\frac{0}{0} \\
\frac{2}{2} \\
0 \\
0\end{array}$ & Criteria \\
\hline 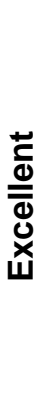 & 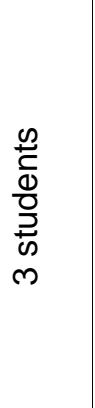 & 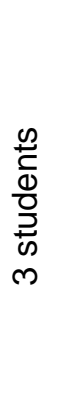 & $\begin{array}{l}\text { The student spoke fluently; s/he } \\
\text { made few mistakes, gave the } \\
\text { necessary explanations and } \\
\text { arguments, supporting them with } \\
\text { appropriate examples. His/her } \\
\text { mother tongue influences his/her } \\
\text { pronunciation only to a very small } \\
\text { extent. In terms of grammar and } \\
\text { vocabulary, the student made only } \\
2-3 \text { small mistakes. }\end{array}$ \\
\hline 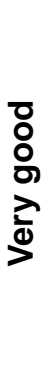 & 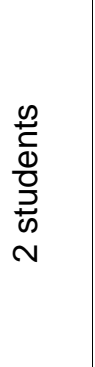 & $\begin{array}{l}\frac{n}{0} \\
\frac{1}{d} \\
\frac{0}{D} \\
\stackrel{0}{c} \\
m\end{array}$ & $\begin{array}{l}\text { The student spoke with ease, } \\
\text { making only several mistakes that } \\
\text { did not change or influence the } \\
\text { meaning of the message. His/her } \\
\text { mother tongue slightly influences } \\
\text { his/her pronunciation. In terms of } \\
\text { grammar and vocabulary, the } \\
\text { student made only a few mistakes, } \\
\text { most sentences being correct. }\end{array}$ \\
\hline $\begin{array}{l}\text { 음 } \\
\text { ○ }\end{array}$ & 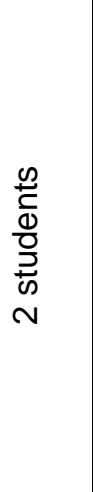 & $\begin{array}{l}\frac{n}{0} \\
\frac{0}{0} \\
\frac{0}{0} \\
0 \\
\infty \\
m\end{array}$ & $\begin{array}{l}\text { The student spoke with ease, } \\
\text { making only several mistakes that } \\
\text { slightly changed or influenced the } \\
\text { meaning of the message. His/her } \\
\text { mother tongue influences his/her } \\
\text { pronunciation moderately; } \\
\text { however, there were no serious } \\
\text { phonological errors. In terms of } \\
\text { grammar and vocabulary, the } \\
\text { student made only a few small } \\
\text { mistakes, with only 1-2 major } \\
\text { errors causing confusion. }\end{array}$ \\
\hline $\begin{array}{l}0 \\
\stackrel{\varpi}{0} \\
0\end{array}$ & 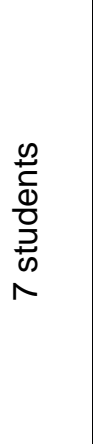 & 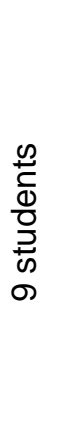 & $\begin{array}{l}\text { The student spoke hesitantly, } \\
\text { conveyed the required messages, } \\
\text { but s/he made serious mistakes. } \\
\text { The student's vocabulary is limited. } \\
\text { His/her mother tongue influences } \\
\text { his/her pronunciation; s/he made } \\
\text { only a few serious phonological } \\
\text { and lexical mistakes and some of } \\
\text { them created confusion in terms of } \\
\text { understanding the conveyed } \\
\text { message. }\end{array}$ \\
\hline
\end{tabular}


"Mircea cel Batran" Naval Academy Scientific Bulletin, Volume XX - 2017 - Issue 2

The journal is indexed in: PROQUEST / DOAJ / Crossref / EBSCOhost/ INDEX COPERNICUS/ OAJI / DRJI / JOURNAL INDEX / I2OR / SCIENCE LIBRARY INDEX / Google Scholar / Academic Keys / ROAD Open Access I Academic Resources / Scientific Indexing Services I SCIPIOI JIFACTOR

\begin{tabular}{|c|c|c|c|}
\hline 离 & $\begin{array}{l}\frac{0}{\frac{1}{0}} \\
\frac{0}{0} \\
\frac{D}{2} \\
m\end{array}$ & 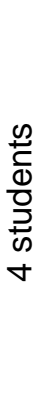 & $\begin{array}{l}\text { The student had difficulties in } \\
\text { transmitting his/her message and } \\
\text { s/he made frequent mistakes that } \\
\text { entailed communication } \\
\text { breakdowns. The student's } \\
\text { vocabulary is poor. His/her mother } \\
\text { tongue influences heavily his/her } \\
\text { pronunciation. In terms of grammar } \\
\text { and vocabulary, the student made } \\
\text { many basic mistakes. }\end{array}$ \\
\hline $\begin{array}{l}\frac{1}{0} \\
\vdots \\
\frac{2}{2} \\
\frac{2}{j}\end{array}$ & $\begin{array}{l}\frac{0}{\frac{1}{0}} \\
\frac{0}{0} \\
\frac{D}{2} \\
m \\
m\end{array}$ & $\begin{array}{l}\frac{0}{\frac{1}{0}} \\
\frac{0}{0} \\
\frac{D}{2} \\
m \\
m\end{array}$ & $\begin{array}{l}\text { The student's English is very poor; } \\
\text { s/he could hardly transmit a } \\
\text { message and made serious } \\
\text { mistakes in terms of pronunciation, } \\
\text { grammar and vocabulary. There is } \\
\text { no evidence that they master } \\
\text { English speaking skills. }\end{array}$ \\
\hline
\end{tabular}

Source: Authors' own processing

The initial marks obtained by the experimental group students revealed that $70 \%$ passed the test and $30 \%$ failed it.

Table 2. Initial test marks - the experimental group

\begin{tabular}{|c|c|c|c|c|}
\hline 赵 & under 5 & $\begin{array}{c}\text { between } \\
5-6,99\end{array}$ & $\begin{array}{c}\text { between } \\
7-8,99\end{array}$ & $\begin{array}{c}\text { between } \\
9-10\end{array}$ \\
\hline$\sum^{\infty}$ & 6 & 7 & 4 & 3 \\
\hline 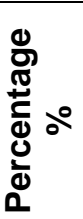 & $30 \%$ & $35 \%$ & $20 \%$ & $15 \%$ \\
\hline
\end{tabular}

Source: Authors' own processing

The marks obtained by the control group students in the initial test reveal that $64 \%$ passed it while $36 \%$ failed it.

Table 3. Initial test marks - the control group

\begin{tabular}{|c|c|c|c|c|}
\hline ֶֻ & under 5 & \begin{tabular}{|c|} 
between \\
$5-6,99$
\end{tabular} & $\begin{array}{c}\text { between } \\
7-8,99\end{array}$ & $\begin{array}{c}\text { between } \\
9-10\end{array}$ \\
\hline$\sum$ & 9 & 9 & 4 & 3 \\
\hline 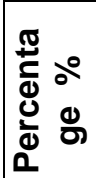 & $36 \%$ & $36 \%$ & $16 \%$ & $12 \%$ \\
\hline
\end{tabular}

Source: Authors' own processing

These results reveal that not all the students had a highly developed ability to interact, to speak in a range of contexts and to balance accuracy and fluency. Pronunciation errors were minor as they did not impede meaning processing. Some of the students could hardly convey messages, made serious mistakes and required additional prompting and support.

The initial test results showed that the control group students and the experimental group students had similar ESP levels, as far as their speaking skills were concerned, before applying cooperative learning.

During the experiment, two ESP units were taught, i.e. Tomorrow's World and Job Interviews.

The control group students were taught through traditional learning methods, focused on teacher-centered instruction. The students were asked to preview the text for each unit before class, and the teacher instructed the whole class by explaining the text to be discussed, focusing on English grammar and vocabulary items. The teacher interacted with the students by asking questions and leading a discussion. Therefore, there was little student interaction. Questions were usually direct and the students had to repeat the answers, this method encouraging route learning and memorizing. The teacher did not encourage communication between students. The control group students passed individual tests (focused on the two above-mentioned units) at the end of the experiment.

The experimental group students were divided into small heterogeneous groups of four members. In the first two weeks of the experiment, the teacher spent about 10 minutes at the beginning of every ESP class guiding students to practise cooperative learning speaking strategies and skills through explanation and teaching. The cooperative learning strategies used by the teacher during the experiment included Jigsaw, Think-Pair Share, Flashcards and Three-Step Interview.

In the cooperative learning classes, students were asked to preview the unit text and prepare individual questions before class, and then bring the questions to class for discussing them in groups and pairs. During class cooperation, group members clarified word meanings and confusing texts, with a special focus on those embedding also cultural concepts and values, such as ESP idiomatic expressions (in this regard, see Leonte and Istratie-Macarov, 2016; Istratie-Macarov and Leonte 2016). Then, the students engaged in a discussion to determine the answers to their questions. During group discussions, the teacher helped students cope with misunderstandings, offered feedback, and facilitated discussions. In addition, the students were encouraged to engage in debates and short dialogues, interviews, descriptions, storytelling, summarizing, expressing opinions. Thus, cooperative learning encouraged the students' 
"Mircea cel Batran" Naval Academy Scientific Bulletin, Volume XX - 2017 - Issue 2

The journal is indexed in: PROQUEST / DOAJ / Crossref / EBSCOhost/ INDEX COPERNICUS/ OAJI / DRJI / JOURNAL INDEX / I2OR / SCIENCE LIBRARY INDEX / Google Scholar / Academic Keys / ROAD Open Access I Academic Resources / Scientific Indexing Services / SCIPIOI JIFACTOR

mutual interaction; furthermore, it focused on their active and task-oriented participation in studentcentered learning events.

In the Cooperative Learning activities, students worked in groups or pairs. For instance, in one activity, a student was given several elements (for example a picture) displayed in a certain way, and another student was given the same elements. However, the latter's elements were loose and s/he was asked to arrange them in the same order/way. He would figure the correct order/way out by discussing with his/her partner (s/he was forbidden to look at his/her partner's picture). In another activity, the students from the experimental group were organized in pairs and each student was given similar pictures, but with several small differences. Then, the students had to discuss and to highlight the differences; this time they were forbidden to look at each other's picture.

After the experiment, the students passed a final test, aimed at assessing their ESP teaching skills and comparing the results in order to verify the research hypothesis (i.e. the Cooperative Learning Method in the ESP classroom helps learner to feel more comfortable and enhances their speaking skills).

The structure of the final test was similar to the one of the initial test (i.e. it contained three tasks: answer some questions, talking about picture differences and expressing one's opinion about a particular topic). Moreover, the assessment was based on the same criteria presented above.

The scoring classification of the students' results in terms of their ESP speaking skills are shown in the table below:

Table 4. The students' speaking skills. Classification and criteria (final test results)

\begin{tabular}{|c|c|c|c|}
\hline 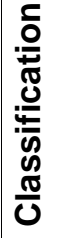 & 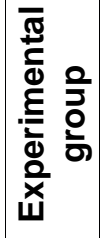 & 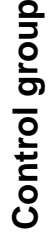 & Criteria \\
\hline
\end{tabular}

\begin{tabular}{|c|c|c|c|}
\hline 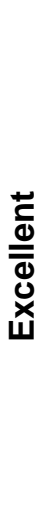 & $\begin{array}{l}\frac{0}{ \pm} \\
\frac{1}{0} \\
\frac{0}{0} \\
\frac{1}{0} \\
0 \\
0\end{array}$ & $\begin{array}{l}\frac{n}{ \pm} \\
\frac{1}{0} \\
\frac{0}{2} \\
\frac{1}{\omega} \\
m\end{array}$ & $\begin{array}{l}\text { The student spoke fluently; s/he } \\
\text { made few mistakes, gave the } \\
\text { necessary explanations and } \\
\text { arguments, supporting them with } \\
\text { appropriate examples. His/her } \\
\text { mother tongue influences his/her } \\
\text { pronunciation only to a very small } \\
\text { extent. In terms of grammar and } \\
\text { vocabulary, the student made only } \\
2-3 \text { small mistakes. S/he has an } \\
\text { excellent level of the speaking } \\
\text { skills acquired and practised in the } \\
\text { ESP seminar. }\end{array}$ \\
\hline 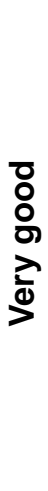 & $\begin{array}{l}\frac{0}{ \pm} \\
\frac{1}{0} \\
\frac{0}{0} \\
\frac{1}{0} \\
0 \\
0\end{array}$ & 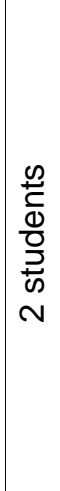 & $\begin{array}{l}\text { The student spoke with ease, } \\
\text { making only several mistakes that } \\
\text { did not change or influence the } \\
\text { meaning of the message. His/her } \\
\text { mother tongue slightly influences } \\
\text { his/her pronunciation. In terms of } \\
\text { grammar and vocabulary, the } \\
\text { student made only a few small } \\
\text { mistakes, most sentences being } \\
\text { correct. S/he has a very good level } \\
\text { of speaking skills acquired and } \\
\text { practised in the ESP seminar. }\end{array}$ \\
\hline & 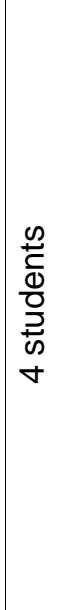 & 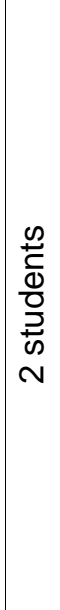 & $\begin{array}{l}\text { The student spoke with ease, } \\
\text { making only several mistakes that } \\
\text { slightly changed or influenced the } \\
\text { meaning of the message. His/her } \\
\text { mother tongue influences his/her } \\
\text { pronunciation moderately; } \\
\text { however, there were no serious } \\
\text { phonological errors. In terms of } \\
\text { grammar and vocabulary, the } \\
\text { student made only a few small } \\
\text { mistakes, with only } 1-2 \text { major errors } \\
\text { causing confusion. S/he has a } \\
\text { good level of speaking skills } \\
\text { acquired and practised in the ESP } \\
\text { seminar. }\end{array}$ \\
\hline 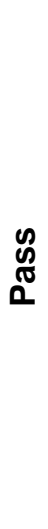 & $\begin{array}{l}\frac{n}{ \pm} \\
\frac{1}{d} \\
\frac{0}{\partial} \\
\frac{7}{n} \\
m\end{array}$ & 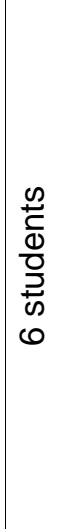 & $\begin{array}{l}\text { The student spoke hesitantly, } \\
\text { conveyed the required messages, } \\
\text { but s/he made serious mistakes. } \\
\text { The student's vocabulary is limited. } \\
\text { His/her mother tongue influences } \\
\text { his/her pronunciation; s/he made } \\
\text { only a few serious phonological } \\
\text { and lexical mistakes and some of } \\
\text { them created confusion in terms of } \\
\text { understanding the conveyed } \\
\text { message. S/he has a quite weak } \\
\text { level of speaking skills acquired } \\
\text { and practised in the ESP seminar. }\end{array}$ \\
\hline
\end{tabular}


"Mircea cel Batran" Naval Academy Scientific Bulletin, Volume XX - 2017 - Issue 2

The journal is indexed in: PROQUEST / DOAJ / Crossref / EBSCOhost/ INDEX COPERNICUS/ OAJI / DRJI / JOURNAL INDEX / I2OR / SCIENCE LIBRARY INDEX / Google Scholar / Academic Keys / ROAD Open Access I Academic Resources / Scientific Indexing Services / SCIPIOI JIFACTOR

\begin{tabular}{|c|c|c|c|}
\hline & 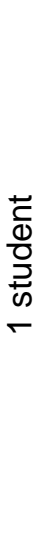 & $\begin{array}{l}\frac{0}{0} \\
\frac{0}{0} \\
\frac{0}{2} \\
\omega \\
m\end{array}$ & $\begin{array}{l}\text { The student had difficulties in } \\
\text { transmitting his/her message and } \\
\text { s/he made frequent mistakes that } \\
\text { entailed communication } \\
\text { breakdowns. The student's } \\
\text { vocabulary is poor. His/her mother } \\
\text { tongue influences heavily his/her } \\
\text { pronunciation. In terms of grammar } \\
\text { and vocabulary, the student made } \\
\text { many basic mistakes. S/he has a } \\
\text { weak level of speaking skills } \\
\text { acquired and practised in the ESP } \\
\text { seminar. }\end{array}$ \\
\hline 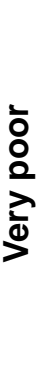 & 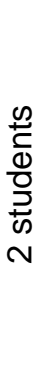 & $\begin{array}{l}\frac{0}{0} \\
\frac{1}{2} \\
\frac{0}{2} \\
0 \\
0 \\
0\end{array}$ & $\begin{array}{l}\text { The student's English is very poor; } \\
\text { s/he could hardly transmit a } \\
\text { message and made serious basic } \\
\text { mistakes in terms of pronunciation, } \\
\text { grammar and vocabulary. There is } \\
\text { no evidence that they have } \\
\text { mastered their English speaking } \\
\text { skills practised in the ESP seminar } \\
\text { (a very weak level). }\end{array}$ \\
\hline
\end{tabular}

Source: Authors' own processing

The marks obtained by the experimental group students in the final Test are presented in the table below, showing that $90 \%$ passed it and only $10 \%$ failed it.

Table 5. Final test marks - the experimental group

\begin{tabular}{|c|c|c|c|c|}
\hline \multirow{2}{*}{ 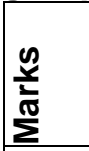 } & under 5 & $\begin{array}{c}\text { between } \\
5-6,99\end{array}$ & \begin{tabular}{|c|} 
between \\
$7-8,99$
\end{tabular} & $\begin{array}{c}\text { between } \\
9-10\end{array}$ \\
\hline & 2 & 4 & 9 & 5 \\
\hline 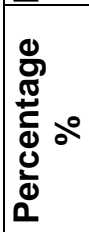 & $10 \%$ & $20 \%$ & $45 \%$ & $25 \%$ \\
\hline
\end{tabular}

Source: Authors' own processing

The final marks obtained by the control group students showed that $72 \%$ passed the test, while $28 \%$ failed it.

Table 6. Final test marks - the control group

\begin{tabular}{|l|c|c|c|c|}
\hline$\underline{\tilde{\sigma}} \boldsymbol{\varrho}$ & under 5 & between & between & between \\
\hline & & $5-6,99$ & $7-8,99$ & $9-10$ \\
\hline
\end{tabular}

\begin{tabular}{|c|c|c|c|c|}
\hline 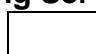 & 7 & 8 & 6 & 4 \\
\hline 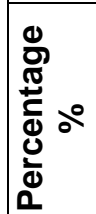 & $28 \%$ & $32 \%$ & $24 \%$ & $16 \%$ \\
\hline
\end{tabular}

Source: Authors' own processing

The data presented above, obtained by observing the traditional and the cooperative teaching and learning processes and by analyzing the students' initial and final test results, revealed that the ESP speaking skills of the experimental group students improved to a great extent (compared with those of control group students), emphasizing thus the benefits of cooperative learning. The pronunciation, fluency, grammar, vocabulary and interactive communication are ESP speaking aspects that the experimental group students improved and developed in their cooperative classroom activities. Moreover, when speaking English, they displayed more confidence, as they had more occasions to express themselves and speak up, within a more enjoyable class atmosphere. Furthermore, it was easier and simpler for the experimental group students to study the provided materials with the other team members, and they participated actively in the cooperative activities, compared with the control group students, who were more reluctant to participate in the activities, being shy, nervous or passive. Gradually, the experimental group students spotted and understood the mistakes they had made because the teacher always asked them to give feedback on their peers' performance.

Overall, the results indicated that the experimental group students benefited from the cooperative learning activities, obtaining comparatively better marks in the assessment of their ESP speaking skills, in comparison with the control group students, who were involved in traditional and teacher-centered activities, revealing that our research hypothesis (i.e. cooperative learning enhances the students' ESP speaking skills, compared to the traditional teaching methods) is valid.

\section{CONCLUSIONS}

Through cooperative learning, ESP speaking activities can become highly motivating and students involve themselves more actively instead of being afraid of making mistakes in front of the whole class. After the experiment, the results and their analysis highlighted that cooperative learning activities helped students to acquire, develop and improve their ESP speaking skills gradually, as they were provided more reasons and opportunities to express themselves and to speak up, and also to employ their previous ESP knowledge by learning and teaching cooperatively and actively. In order to encourage students to speak, appropriate information, enough vocabulary items or correct grammatical structures should be provided. 


\begin{abstract}
"Mircea cel Batran" Naval Academy Scientific Bulletin, Volume XX - 2017 - Issue 2
The journal is indexed in: PROQUEST / DOAJ / Crossref / EBSCOhost/ INDEX COPERNICUS/ OAJI / DRJI I

JOURNAL INDEX / I2OR / SCIENCE LIBRARY INDEX / Google Scholar / Academic Keys / ROAD Open Access I Academic Resources / Scientific Indexing Services / SCIPIOI JIFACTOR
\end{abstract}

Moreover, the teacher should create a learning atmosphere that does not place a great emphasis on mistakes and that offers students the opportunity to get involved into attractive cooperative activities that motivate them to express themselves.

The experiment reveals that there are several elements that play a key role in the cooperative classroom, such as working in small groups (i.e. students should be organized in pairs or in small groups), taking into consideration different ESP levels, establishing team rules, working separately on different aspects involved by the ESP speaking skills, the students' assessment of their peers' performance.

In our opinion, in the cooperative classroom, the control of the students' discipline represented one of the most challenging and important issues. This was triggered by the fact that the students had to work together, and sometimes, especially at the beginning, this contradicted their wishes (for instance, some of them wanted to solve the tasks only together with their friends, or some of them were shy and reluctant to participate because of their new partners).

It is noteworthy that the teacher should explain the rules and objectives of each activity. During the speaking activities, the experimental group students knew their responsibilities and complied with them (individually and at team level). They became gradually aware of the fact that they were provided with many elements and opportunities in order to express themselves and to communicate their messages successfully. The experimental group students became aware that they can acquire, develop and improve their ESP speaking skills only by constantly practising it, using some of the appropriate information provided by the teacher and by their peers. Every activity ended with the teacher's useful feedback, which helped them to get involved in other group discussions. Moreover, they started to correct their mistakes because they were required to check the new vocabulary items and expressions and their pronunciation constantly during the activity.

Furthermore, the cooperative activities established a different class atmosphere; the students did not feel any anxiety and pressure and had a wide variety of opportunities to speak up and express themselves. Therefore, the experimental group students discovered that ESP speaking activities are fun and easy when they involve working with their peers and became aware of the importance of interacting with others, for the development of these skills. Additionally, the experimental group students learnt how to implement several values and social skills, such as honesty, tolerance, solidarity, respect, team spirit and self-esteem; cooperative learning also helped them to establish new relationships with their peers.

Therefore, as far as our experiment is concerned, it was revealed that cooperative learning represented an appropriate method for acquiring, developing and improving the students' ESP speaking skills, this method being enjoyable both for the students and their teacher. The students learnt more, they developed their ESP skills, with a focus on the speaking ones, as they had more occasions to participate and get involved in the cooperative activities and felt comfortable using ESP within their working groups, without the pressure of grades or other students' opinions. All in all, our experiment has shown the positive relationship between cooperative group work and oral performance.

\title{
BIBLIOGRAPHY
}

[1] Adams, A. R. (2013). Cooperative Learning Effects on the Classroom. Master of Arts in Education. Northern Michigan University.

[2] Bawn, S. (2007). The Effects of Cooperative Learning on Learning and Engagement. A Project For the Master in Teaching Degree. Faculty of The Evergreen State College.

[3] Frandsen, B.(1994). Managing Cooperative Classrooms. Family School Publications.

[4] Gillies, R. M. and Ashman, A. F.(2003). Cooperative Learning: The social and intellectual outcomes of learning in groups. London, Routledge Falmer.

[5] Castillo, C. Y. (2007). "Improving Eleventh Graders' Oral Production in English Class through Cooperative Learning Strategies". In Profile: Issues Teachers' Professional Development, p. 75-90

[6] Harmer, J.(2003). Practice of English Language Teaching. (3 $3^{\text {rd }}$ edition). London, Longman.

[7] Istratie-Macarov, A.L., Leonte, A., 2016. "The Play of Familiarity and Predictability in English Business Idioms". Ovidius University Annals, Economic Sciences Series. Vol. XVI (2). pp. 223-226. Constanta: Ovidius University Press.

[8] Jones, L. (2007). The Student-Centered Classroom, Cambridge University Press.

[9] Johnson, D.W., Johnson, R.\& Houlbec, E.(1998). Cooperation in the classroom. (7th edition). Edina, Minnesota: Interaction Book Company.

[10] Leonte, A., Istratie-Macarov, A.L. 2016. "Taking the Bull by the Horns with English Business Idioms". Ovidius University Annals, Economic Sciences Series. Vol. XVI (2). pp. 233-238. Constanta: Ovidius University Press.

[11] Macpherson, A. (2007). Cooperative Learning Group Activities for College Courses - A guide for Instructors. Kwantlen University College. 
"Mircea cel Batran" Naval Academy Scientific Bulletin, Volume XX - 2017 - Issue 2

The journal is indexed in: PROQUEST / DOAJ / Crossref / EBSCOhost/ INDEX COPERNICUS/ OAJI / DRJI I

JOURNAL INDEX / I2OR / SCIENCE LIBRARY INDEX / Google Scholar / Academic Keys / ROAD Open Access I Academic Resources / Scientific Indexing Services / SCIPIOI JIFACTOR

[12] Maruntelu, L. and Dumitrascu, E. (2013). "LSP and Communication Skills for the Economic Student". In Ovidius University Annals, Economic Sciences Series, Vol. XIII, Issue 1, p.63-69.

[13] Maruntelu, L. (2006). "Identifying the Real Value of Communication". In A XII-a sesiune de comunicări ştiinţifice a studenţilor şi a XIII-a sesiune de comunicări ştiinţifice a cadrelor didactice, Universitatea "Spiru Haret" Constanţa, pp. 158-168.

[14] Meng, J. (2010). "Cooperative Learning Method in the Practice of English Reading and Speaking". Journal of Language Teaching and Research. Vol. 1, No. 5, pp. 701-703, Academy Publisher, Finland Ryan, M. Richard and Edward L. Deci (2000). "Intrinsic and Extrinsic Motivations: Classic Definitions and New Directions" in Contemporary Educational Psychology 25, 54-67.

[15] Sanchez, F. (2010). Interactive Classroom Strategies and Structures for Success. Focus on English Learners. Associate Superintendent, Academics \& Professional Development, San Francisco Unified School District.

[16] Stone, J. (2007). Cooperative Learning and English. Hawker Brownlow Education.

[17] Vizental, A. (2007). Strategies of Teaching and Testing English as a Foreign Language, Collegium, Polirom.

[18] Wilwert, M. (2015). Integrating Cooperative Learning Into A Conventional English Foreign Language Classroom. To what extent can cooperative learning be successfully integrated into a conventional EFL classroom? Travail de Candidature. Luxembourg, Lycee Technique de Bonnevoie

[19] Zhang, Y. (2010). Cooperative Language Learning and Foreign Language Learning and Teaching. Journal of Language Teaching and Research,1(1), 81-83. 